Previous studies have shown that mast cell granules (MCG) inhibit numerous macrophage functions including tumour cy totoxicity, superoxide and nitric oxide (NO) production, and FC $\gamma 2$ a receptor-mediated phagocytosis. In this study, the effect of MCG on macrophage TNF $\alpha$ and nitric oxide synthase (iNOS) mRNA expression, and the production and fate of TNF $\alpha$ were ex am in ed. Upon activation with LPS + IFN $\gamma$, macrophages expressed both TNF $\alpha$ and iNOS mRNA and produced both TNF $\alpha$ and NO. Co-incubation of LPS+IFN $\gamma$-activated macrophages with MCG resulted in dose-dependent inhibition of iNOS mRNA expression. TNF $\alpha$ production in the activated macrophages was decreased by MCG, which was associated with a reduction in TNF $\alpha$ m RNA expression. MCG were also capable of degrading both $m$ acrophage-generated and recombinant TNF $\alpha$. The direct effect of MCG on TNF $\alpha$ was partially reversed by a mixture of protease inhibitors. These results demonstrate that MCG decrease the production of NO and TNF $\alpha$ by in hibiting macrophage iNOS and TNF $\alpha$ gene expression. Furthermore, MCG post-transcriptionally alter TNF $\alpha$ levels via proteolytic degradation.

Key words: Nitric oxide, TNF $\boldsymbol{\alpha}$, Macrophages, Mast cell granules, Proteases

\section{Effect of mast cell granules on the gene expression of nitric oxide synthase and tumour necrosis factor- $\alpha$ in macrophages}

\author{
Y. Li, T. D. Nguyen, A. C. Stechschulte, \\ D. J. Stechschulte and K. N. Dileepan ${ }^{\mathrm{CA}}$
}

Division of Allergy, Clinical Immunology and

Rheumatology, Department of Medicine, University of Kansas Medical Center, 3901 Rainbow Boulevard, Kansas City, KS 66160, USA

${ }^{\mathrm{CA}}$ Corresponding Author
Tel: (+1) 9135883818
Fax: (+1) 9135883987

\section{Introduction}

Macrophages play a major role in microbicidal and tumoricidal activity, antigen presentation, and the production of a variety of cytokines and inflammatory mediators. ${ }^{1,2}$ Mast cells, on the other hand, play a key role in hypersensitivity reactions by secreting mediators such as histamine, proteoglycans, various cytokines, metabolites of arachidonate and unique proteases. ${ }^{3-6}$ The recruitment of macrophages to sites of mast cell degranulation and the subsequent phagocytosis of granules in vivo was first reported by Fawcett. ${ }^{7}$ We have previously shown that mast cell granules (MCG) interact with rodent macrophages and downregulate superoxide production, ${ }^{8-10}$ tumour cell killing and NO production. ${ }^{11}$ These reports confirm that mast cell-macrophage communication has a regulatory effect on host defence mechanisms and inflammation. A role for mast cells in tumour growth and metastasis is evident by the presence of an increased number of mast cells at the periphery of certain tumours ${ }^{12-14}$ and by the angiogenic activity of several mast cell products. ${ }^{15,16}$ Similarly, macrophage products such as NO and TNFa are implicated in tumour grow th and inflammation. The fact that increased number of mast cells are found in the periphery of tumours and MCG interaction inhibited macrophage-mediated tumour cell killing prompted us to examine the mechanism of the effect of MCG on macrophage NO and TNF $\alpha$ production. The focus of this study was, therefore, to examine the effect of MCG on mRNA ex pression of iNOS and TNFa in macrophages. The results demonstrate that MCG interact with macrophages, inhibit iNOS and TNFa mRNA expression, and degrade TNF $\alpha$.

\section{Materials and methods}

\section{Materials}

Lipopolysaccharide (LPS) from Escherichia coli cell wall, penicillin, streptomycin, HEPES, metrizamide, leupeptin, pepstatin A, aprotinin, phenylmethylsulfonyl fluoride (PMSF) and thiazolyl blue dye (MTT) were purchased from Sigma Chemical Co. (St Louis, MO). Soybean trypsin inhibitor was purchased from Boehringer Mannheim (Indianapolis, IN). Heparin solution was supplied by Elkins-Sinn, Inc. (Cherry Hill, NJ). Minimum essential medium with Earle's salts (MEM) and fetal bovine serum were obtained from Hyclone Laboratories (Logan, UT). The ELISA kit for mouse TNF $\alpha$ was purchased from Genzyme (Cambridge, MA). Plastek M cell culture plates were from Mat Tek Co. (Ashland, MA). The RNA Stat-60 kit was purchased from Tel-Test, Inc. (Friendswood, TX). All tissue culture reagents used in this study were free from de tectable levels of endotox in $(<25 \mathrm{pg} / \mathrm{ml})$ when tested by the limulus amoebocyte lysate gel-clot assay (Associates of Cape Cod, Inc., Woods Hole, MA). 


\section{Animals}

Male Sprague-Dawley rats $(350-400 \mathrm{~g})$ used for harvesting mast cells, and male C57BL/6J mice (2-3 months old), the source of macrophages, were purchased from Harlan Co., Indianapolis, Indiana.

\section{Harvesting and culture of murine peritoneal macrophages}

Three days prior to harvesting peritoneal exudates, each mouse was injected intraperitoneally with $1.5 \mathrm{ml}$ of a sterile solution of proteose peptone $(10 \% \mathrm{w} / \mathrm{v})$. The peritoneal cavity of each mouse was lavaged twice with $2.5 \mathrm{ml}$ of minimum essential medium containing $15 \mathrm{mM}$ HEPES, 100 units $\mathrm{ml}$ of penicillin, $100 \mu \mathrm{g} / \mathrm{ml}$ streptomycin, $10 \%$ fetal bovine serum (HMEM) and 5 units/ml of heparin. The pooled cell suspension was sedimented by centrifugation at 250 $\times \boldsymbol{g}$ for $10 \mathrm{~min}$, washed twice and resuspended in HMEM without heparin. Aliquots of the cell suspension containing $2 \times 10^{5}$ cells were seeded in each well of a 96-well culture plate. Non-adherent cells were removed by washing after $2-4 \mathrm{~h}$ of incubation at $37^{\circ} \mathrm{C}$. Macrophages were activated with LPS (100 ng/ $\mathrm{ml})+\mathrm{IFN} \gamma(10$ units $/ \mathrm{ml})$ in all ex periments, since this concentrations have been found to induce optimum activation.

\section{Isolation of mast cells}

The method employed for the isolation of mast cells has been previously described. ${ }^{11,17}$ In brief, mast cells were collected by lavage of the peritoneal and thoracic cavities of adult rats with $50 \mathrm{ml}$ HMEM containing 5 units $/ \mathrm{ml}$ heparin. The lavaged cells from all animals were pooled, centrifuged at $250 \times \boldsymbol{g}$ for $10 \mathrm{~min}$ at room temperature, and washed twice with HMEM. Tw o $\mathrm{ml}$ of the cell suspension containing 6-8 $\times 10^{7}$ cells were gently layered on a $3 \mathrm{ml}$ cushion of $22.5 \%(\mathrm{w} / \mathrm{v})$ metrizamide (density $1.125 \mathrm{~g} / \mathrm{ml}$ ) in HMEM in a $15 \mathrm{ml}$ centrifuge tube, and centrifuged at $200 \times \boldsymbol{g}$ for $15 \mathrm{~min}$ at room temperature. Mast cells were sedimented at the bottom of the conical tube while other cells (predominantly macrophages) collected at the interface. The mast cell fractions were collected, washed twice, and resuspended in HMEM without heparin. Purity and viability of mast cells isolated by this procedure exceeded $95 \%$.

\section{Preparation of MCG and MCG sonicate}

Under sterile conditions at $0-4^{\circ} \mathrm{C}$, MCG were prepared from metrizamide-purified mast cells by controlled sonication and sucrose gradient centrifugation. Mast cells were suspended in $1 \mathrm{ml}$ of HMEM and sonicated twice for $20 \mathrm{~s}$ with a microtip sonicator (Sonifier Cell Disruptor, model W140) at a power setting of 2.5 and temperature of $4^{\circ} \mathrm{C}$. ${ }^{9,18}$ The disrupted cells were incubated at $30^{\circ} \mathrm{C}$ for $15 \mathrm{~min}$ and mixed vigorously for $1 \mathrm{~min}$. The sonicate was layered on $2 \mathrm{ml}$ of $0.34 \mathrm{M}$ sucrose and centrifuged at $50 \times \boldsymbol{g}$ for $10 \mathrm{~min}$ at $4^{\circ} \mathrm{C}$. The granules at the interface were collected and sedimented by centrifugation at $1800 \times$ $g$ for $20 \mathrm{~min}$ at $4^{\circ} \mathrm{C}$. The resulting pellet consisting of a homogeneous preparation of MCG was washed twice and resuspended in the culture medium. The recovery of granules isolated by this procedure ranged from $60 \%$ to $80 \%$ based on the histamine content of the starting mast cells.

MCG-sonicate was prepared by sonicating purified MCG in HMEM three times for $30 \mathrm{~s}$ at maximum power. The quantity of MCG and MCG-sonicate used in each experiment was expressed as the equivalent of the starting mast cell number.

\section{Assay of TNF $\alpha$}

The concentration of TNF $\alpha$ in the culture medium was assayed by both ELISA and bioassay. The sensitivity of ELISA is $31 \mathrm{pg} / \mathrm{ml}$ using the protocol recommended by the manufacturer. For the bioassay, the target L929 cells in RPMI-1640 medium were seeded $\left(4.2 \times 10^{4}\right.$ per well $)$ in a $96-w e l l$ culture plate. After $18 \mathrm{~h}$ of culture, medium was replaced with $5 \mu \mathrm{g} / \mathrm{ml}$ of dactinomycin in RPMI. Two to $4 \mathrm{~h}$ after incubation with dactino mycin, serially diluted samples and TNFa standards $(2-250 \mathrm{pg} / \mathrm{ml})$ were added and incubated for an additional $18-24 \mathrm{~h}$. The medium was then removed, and $1 \mathrm{mg} / \mathrm{ml}$ of MTT dye in RPMI (w ithout serum and phenol red) was added. After $2-3 \mathrm{~h}$ of incubation, the medium was aspirated completely, and $100 \mu \mathrm{l}$ of 2-propanol was added to each well. The plate was agitated for $10 \mathrm{~min}$ on an orbital shaker and read on a microtitre plate reader at $595 \mathrm{~nm}$.

\section{Analysis of iNOS and TNF $\alpha$ mRNA expression}

Mouse peritoneal cells which contained $>85 \%$ macrophages were seeded in a $10 \mathrm{~cm}$ Petri dish and incubated for $4 \mathrm{~h}$ to allow for macrophage adherence. After washing three times with HMEM, the cells were treated with MCG and activated with LPS + IFN $\gamma$. At selected time points after activation, culture medium was re moved, and the total cellular RNA was ex tracted using an RNA extraction kit. Total RNA $(10 \mu \mathrm{g})$ was electrophoresed on $0.8 \%$ agarose-formaldehyde gel and then transferred to Nytran nylon membrane. After $2 \mathrm{~h}$ of prehybridization, the membrane was hybridized with ${ }^{32}$ P-labelled cDNA probe specific for murine iNOS, TNF $\alpha$ or $\beta$-actin. The probes were labelled by random hexamer priming method using $\left[\alpha_{-}{ }^{32} \mathrm{P}\right] \mathrm{dCTP}$ as previously described. ${ }^{19}$ The membrane was then washed four times and autoradiographed on a Kodak X-OMAT-AR film. A scanner $w$ as used to determine the density of the mRNA band and the relative density of each band was normalized to $\beta$-actin. 


\section{Treatment of MCG with protease inhibitors}

MCG were incubated with a mixture of protease inhibitors containing PMSF $2.5 \mathrm{mM}$, pepstatin A $5 \mu \mathrm{g} / \mathrm{ml}$, trypsin inhibitor $50 \mu \mathrm{g} / \mathrm{ml}$, leupeptin $50 \mu \mathrm{g} / \mathrm{ml}$, and aprotinin $50 \mu \mathrm{g} / \mathrm{ml}$, at $37^{\circ} \mathrm{C}$ for $2 \mathrm{~h}$. The protease inhibitor-treated MCG were then evaluated for their effects on macrophages.

\section{Statistical analysis}

Whenever applicable, the data were analysed by oneway analysis of variance with subsequent StudentNew man-Kuels' test. All results were expressed as means \pm SEM and $P<0.05 \mathrm{w}$ as considered significant.

\section{Results}

\section{Effects of MCG on macrophage iNOS mRNA expression}

Earlier work demonstrated that MCG inhibit macrophage NO production. ${ }^{11}$ To investigate the mechanism, the effect of MCG on macrophage iNOS mRNA expression was analysed at selected mast cell-tomacrophage ratios. The addition of MCG simultaneously with LPS+IFN $\gamma$ to macrophage monolayer inhibited iNOS mRNA expression in a dose-dependent

\section{$\begin{array}{llllll}1 & 2 & 3 & 4 & 5 & 6\end{array}$}

\section{iNOS}

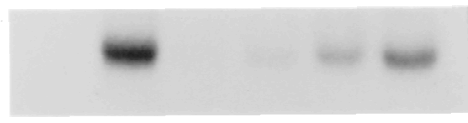

$28 \mathrm{~S}$

\section{$\beta$-actin}

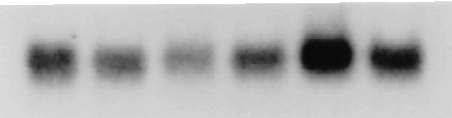

$18 \mathrm{~S}$

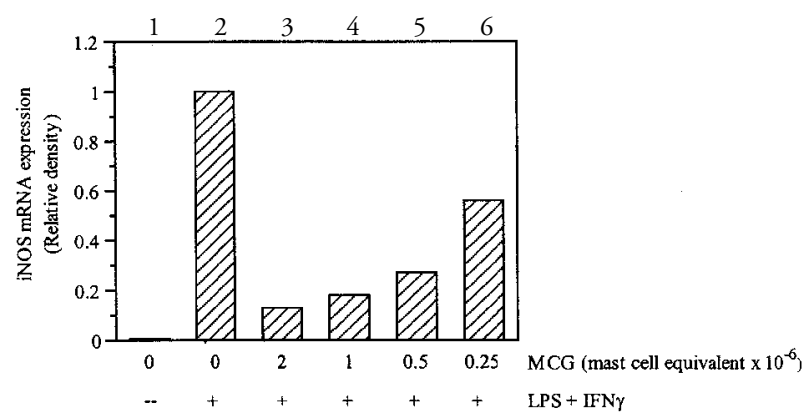

FIG. 1. Effect of MCG on macrophage iNOS mRNA expression. Adherent macrophages $\left(1 \times 10^{7}\right)$ were exposed to the indicated doses of MCG (mast cell equivalent) and activated with LPS (100 ng/ml) + IFN $\gamma$ (10 units/ml). In all subsequent experiments the macrophages were activated with these concentrations. Eighteen hours after activation, iNOS and $\beta$-actin mRNA were analysed by Northern blotting. The $\beta$-actin expression was used to normalize the data. For top panel: lane 1. control; lane 2. LPS +IFN $\gamma$; lane 3. LPS+IFN $\gamma$ +MCG $2 \times 10^{6}$; lane 4. LPS+IFN $\gamma+$ MCG $1 \times 10^{6}$; lane 5. LPS+FN $\gamma+$ MCG $0.5 \times 10^{6}$; lane 6. LPS+IFN $\gamma+$ MCG $0.25 \times 10^{6}$. This is representative of three experiments.

$\begin{array}{rrrrrr}\text { MCG addition time } & & -24 \mathrm{~h} & -6 \mathrm{~h} & -3 \mathrm{~h} & 0 \mathrm{~h} \\ \mathrm{MCG} & -- & + & + & + & + \\ \text { LPS + IFNy } & + & + & + & + & +\end{array}$

\section{iNOS}

$\beta$-actin
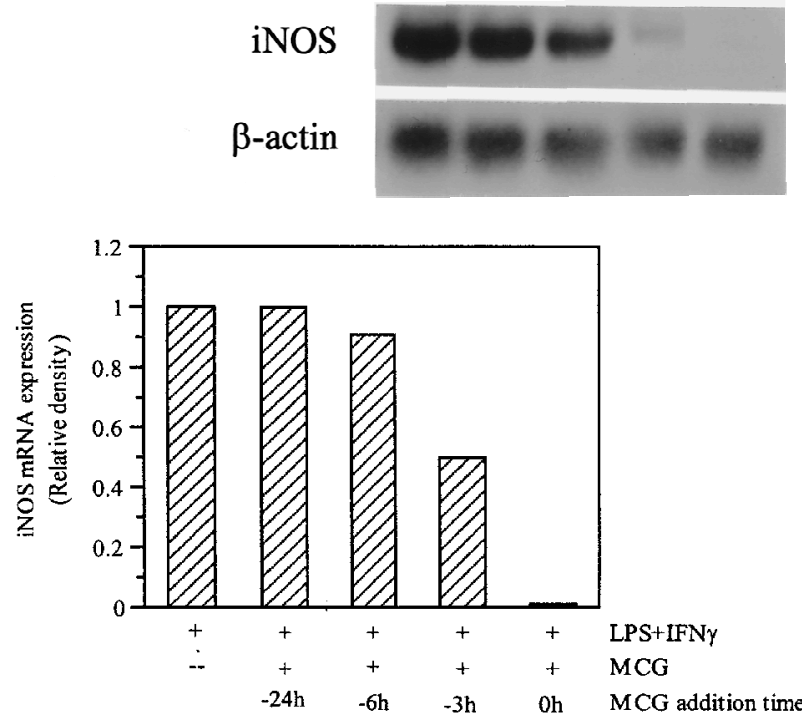

FIG. 2. Effect of pre-treatment of macrophages with MCG on iNOS mRNA expression. Macrophages $\left(1 \times 10^{7}\right)$ were cultured with MCG $\left(2 \times 10^{6}\right.$ mast cell equival ent $)$ for 24,6 and $3 \mathrm{~h}$ prior to activation or added simultaneously with LPS + IFN $\gamma$. Eighteen hours after activation, iNOS and $\beta$-actin mRNA were analysed by Northern blotting. The $\beta$-actin expression was used to normalize the data. This is representative of three experiments.

manner (Fig. 1). Maximal inhibition was noted at a MCG dose equivalent to a mast cell-to-macrophage ratio of $1: 5$ and the inhibition was evident even at a ratio of $1: 40$. When macrophages were pre-incubated with MCG for $3 \mathrm{~h}$ prior to activation, the inhibitory effect of MCG decreased compared with simultaneous addition of MCG and the activators. Furthermore, if macrophages were incubated with MCG for more than $6 \mathrm{~h}$ prior to activation, there was no inhibition of the expression of iNOS transcript (Fig. 2).

\section{Effects of MCG on TNFa production}

When activated with LPS+IFN $\gamma$, macrophages generated large amounts of TNF $\alpha$. Addition of MCG or MCG-S at the time of LPS+IFN $\gamma$ stimulation resulted in dose-dependent decrease in TNF $\alpha$ levels and more than a $90 \%$ decrease was noted at a MCG dose equivalent to a mast cell-to-macrophage ratio of 1.5 to 2 (Fig. 3). The MCG-induced decrease in TNFa levels was seen when determined by ELISA (Fig. 3A) and by bioassay (Fig. 3B). Although the assayed values differed for the same samples depending on the assay method employed, the decrease of TNF $\alpha$ levels was evident. There was no statistically significant difference between the effects of MCG and MCG-S. Therefore, in later experiments only the intact MCG were used. Unactivated macrophages or those 


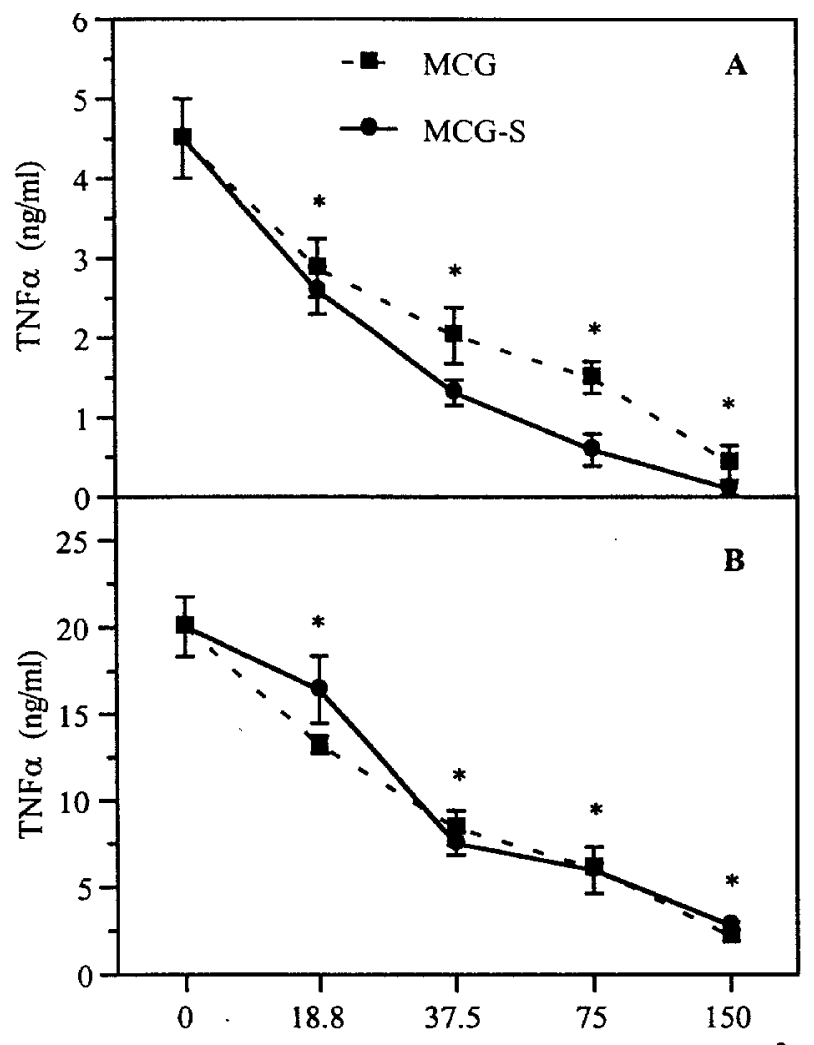

MCG or MCG-S dose ( mast cell equivalent $\times 10^{-3}$ )

FIG. 3. Dose response effect of MCG or MCG-S on macrophage TNF $\alpha$ production. Adherent macrophages $(200,000)$ were cultured with LPS + IFN $\gamma$ in the presence or absence of the indicated doses of MCG or MCG-S (mast cell equivalent). After $6 \mathrm{~h}$ of culture, media were collected and TNF $\alpha$ levels were measured by ELISA (panel A) and bio-assay (panel B) utilizing L929 cells as the target. Each value presented is the mean \pm SEM of quadruplicate determinations. There is no significant difference between the effects of MCG and MCG$\mathrm{S}$. This is representative of three experiments. ${ }^{*} P<0.05$ vs. no MCG added.

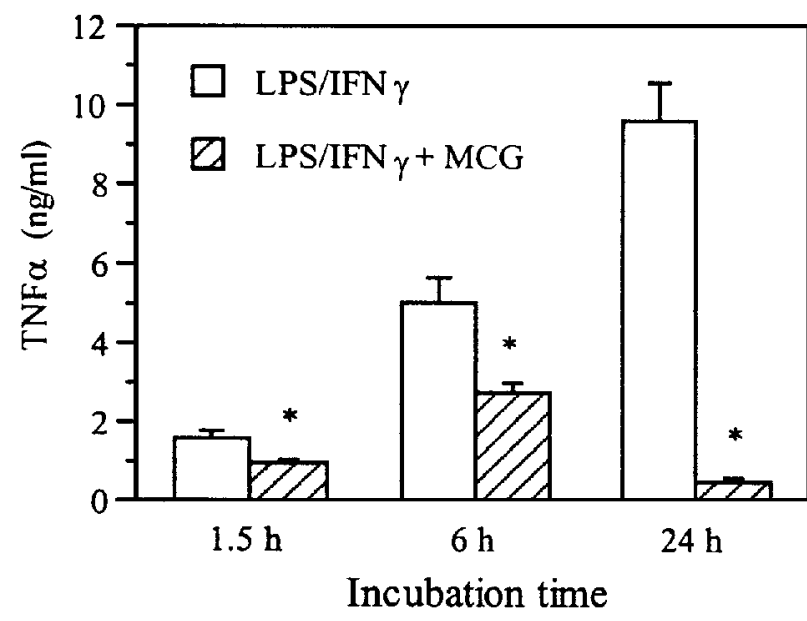

FIG. 4. Time course of the effect of MCG on macrophage secreted TNF $\alpha$ levels. Adherent macrophages $(200,000)$ were cultured with LPS + IFN $\gamma$ in the presence or absence of MCG (100000 mast cell equival ent). After the indicated times, media were collected and TNF $\alpha$ levels were measured by ELISA. Each value presented is the mean \pm SEM of quadruplicate determinations. This is representative of two experiments. ${ }^{*} P<0.05$ vs. LPS+IFN $\gamma$ only at the same time point. exposed only to MCG or MCG-S did not produce detectable levels of TNF $\alpha$.

The production of TNF $\alpha$ by macrophages was evident as early as $1.5 \mathrm{~h}$ after activation. The cumulative TNFo level increased for up to $24 \mathrm{~h}$ while the rate of production appeared to decrease (Fig. 4). The presence of MCG decreased the level of TNFa by approximately $40 \%$ at 1.5 and $6 \mathrm{~h}$ in contrast to a $95 \%$ decrease at $24 \mathrm{~h}$. This effect was also evident when TNF $\alpha$ was assayed by bioassay (data not shown).

\section{Effects of MCG on TNFa mRNA expression}

In order to assess the effect of MCG on TNF $\alpha$ mRNA expression by activated macrophages, the transcripts were analysed at 2, 6 and $24 \mathrm{~h}$ of incubation after activation. The result demonstrates that TNF $\alpha$ mRNA was rapidly expressed to a maximal level within $2 \mathrm{~h}$ after activation and then declined thereafter (Fig. 5). Addition of MCG to LPS+IFN $\gamma$-stimulated macrophages inhibited TNF $\alpha$ mRNA expression by $60 \%$ at a mast cell-to-macrophage ratio of $1: 3$.

\section{Effect of MCG proteases on TNF $\alpha$ degradation}

Rat mast cell granules contain a variety of proteases including tryptase, chymase, and carboxypepti-

\begin{tabular}{|c|c|c|c|}
\hline Incubation time & 2 h & $6 \mathrm{~h}$ & $24 \mathrm{~h}$ \\
\hline & + & + & + \\
\hline MC & - & -- & -- \\
\hline
\end{tabular}

TNF $\alpha$

$\beta$-actin

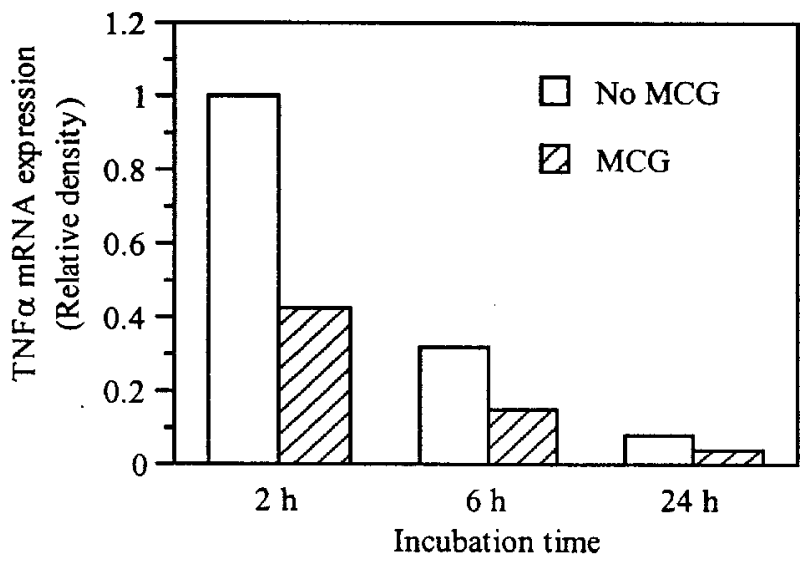

FIG. 5. Effect of MCG on macrophage TNF $\alpha$ mRNA expression. Macrophages $\left(1.5 \times 10^{7}\right)$ were cultured without or with MCG ( $5 \times 10^{6}$ mast cell equivalent) and simultaneously activated with LPS + IFN $\gamma$. After the indicated culture times, TNF $\alpha$ and $\beta$-actin mRNA were analysed by Northern blotting. The $\beta$-actin expression was used to normalize the data. This is representative of three experiments. 


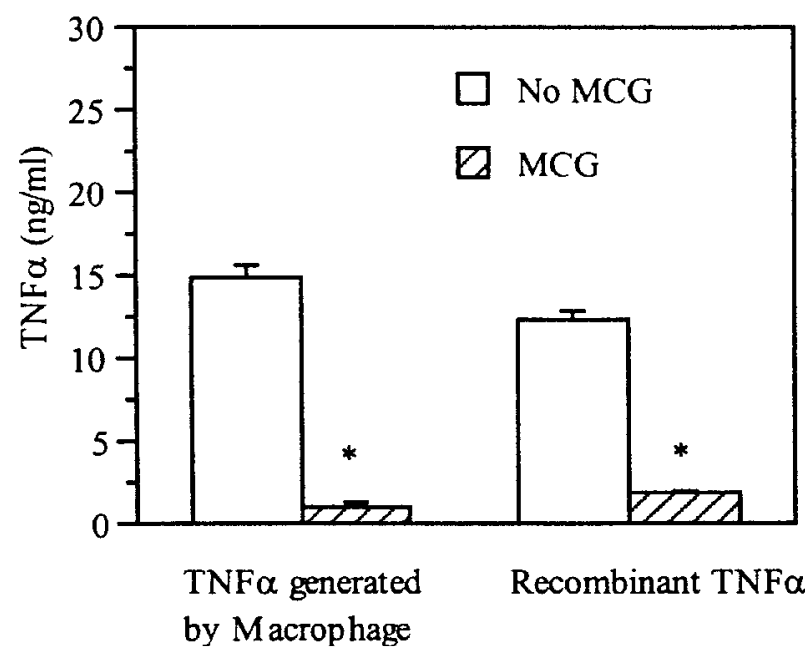

FIG. 6. TNF $\alpha$ degradation by MCG. Macrophage derived and recombinant TNF $\alpha$ were incubated with MCG $(100,000$ mast cell equivalent) in a volume of $0.2 \mathrm{ml}$ culture medium for $24 \mathrm{~h}$. TNF $\alpha$ was assayed by ELISA. Values presented are the mean \pm SEM of quadruplicate determinations. This is a representative of four experiments. ${ }^{*} P<0.05$ vs. no MCG.

dase. $^{20-23}$ To investigate if TNF $\alpha$ is susceptible to these enzymes, conditioned media with known levels of TNF $\alpha$ from LPS+IFN $\gamma$-activated macrophages or recombinant mouse TNF $\alpha$ were incubated w ith MCG for $24 \mathrm{~h}$ at $37^{\circ} \mathrm{C}$. The TNF $\alpha$ levels, assayed by ELISA, indicate that both recombinant and macrophagesecreted TNF $\alpha$ were degraded by MCG (Fig. 6). This effect was partially reversed by the pre-treatment of MCG with a mix ture of protease inhibitors containing

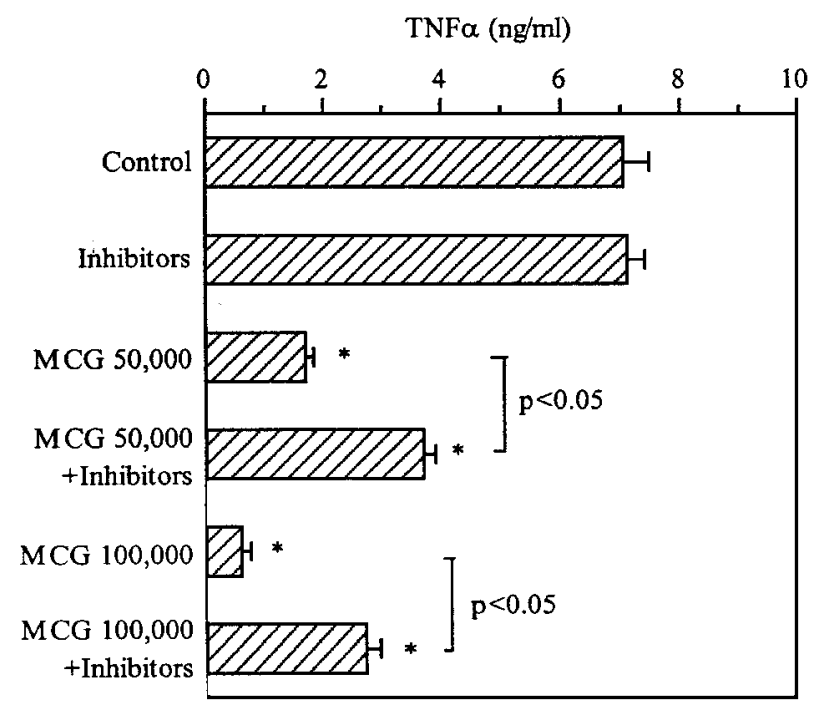

FIG. 7. Effect of protease inhibitors on TNF $\alpha$ degradation by MCG. Mouse recombinant TNF $\alpha$ was incubated with the indicated doses of MCG in cell culture medium for $24 \mathrm{~h}$. MCG were incubated with the protease inhibitor mixture at $37^{\circ} \mathrm{C}$ for $2 \mathrm{~h}$ before being added to TNF $\alpha$. The TNF $\alpha$ levels were assayed by ELISA. Values presented are the mean \pm SEM of quadruplicate determinations. The protease inhibitor mixture contains $2.5 \mathrm{mM}$ PMSF, $5 \mu \mathrm{g} / \mathrm{ml}$ pepstatin A, $50 \mu \mathrm{g} / \mathrm{ml}$ each of trypsin inhibitor, leupeptin and aprotinin. This is representative of three experiments. ${ }^{*} P<0.05$ vs. control.
PMSF, pepstatin A, trypsin inhibitor, leupeptin and aprotinin (Fig. 7). The complete abrogation of TNF $\alpha$ degradation by MCG could not be achieved even after extending the pre-treatment of MCG with these protease inhibitors to $24 \mathrm{~h}$ at $4^{\circ} \mathrm{C}$.

\section{Discussion}

The present study demonstrates that incubation of macrophages with MCG during activation with LPS + INF $\gamma$ results in the inhibition of iNOS and TNF $\alpha$ mRNA expression with a consequent decrease in NO and TNF $\alpha$ production. This corroborates our previous report documenting MCG inhibition of NO production and tumour cell killing by LPS+INF $\gamma$-activated macrophages. ${ }^{11}$ The MCG effect was evident even at an estimated mast cell to macrophage ratio of $1: 40$, a relationship likely to occur in vivo. The inhibitory effect of MCG on macrophage iNOS mRNA expression seems transient because this effect disappears when the macrophages were pre-incubated with MCG for $6 \mathrm{~h}$ or more. The same phenomenon was observed with the inhibitory effect of MCG on TNF $\alpha$ mRNA expression (data not shown). Our earlier studies have ruled out the possibilities that MCG may inactivate LPS or IFN $\gamma$. Further investigation is needed to clarify the mechanism by which MCG inhibit macrophage iNOS and TNF $\alpha$ mRA expression in a transient manner.

The expression of TNF $\alpha$ by activated macrophages is of particular significance since the genes encoding iNOS and TNF $\alpha$ can be coordinately regulated. In vivo studies have suggested a role for TNFo in the positive regulation of iNOS follow ing LPS injection. Anti-TNF $\alpha$ antibodies or soluble TNFa receptor antagonists partially block LPS-induced pulmonary iNOS activity or hepatic iNOS mRNA expression respectively. ${ }^{24,25}$ Furthermore, the involvement of TNF $\alpha$ in both the induction and maintenance of iNOS mRNA in macrophages was recently reported using an in vivo mouse model. ${ }^{26}$ These studies indicate that TNF $\alpha$ is an autocrine regulator of iNOS expression. The TNF $\alpha$ mRNA expression begins as early as $0.5 \mathrm{~h},{ }^{27}$ whereas iNOS mRNA cannot be detected until $8 \mathrm{~h}$ after activation. $^{28}$ Our data also show that TNF $\alpha$ mRNA expression by macrophages is optimal at $2 \mathrm{~h}$ after activation and then progressively decreases. Based on those data we conclude that the depletion of macrophage-secreted TNF $\alpha$ by MCG could contribute to inhibition of LPS-induced iNOS mRNA expression. It is clear that the MCG to macrophage ratio that completely inhibits the expression of iNOS mRNA only partially inhibits the expression of TNF $\alpha$ mRNA. We do not yet have an explanation for this phenomenon. It is possible that the iNOS expression needs a finite amount of TNF $\alpha$ to trigger the gene.

Rodent mast cells contain histamine, serotonin, and proteases including serine proteases, neutral 
proteases, and carboxypeptidase $\mathrm{A}^{20-23}$ Histamine and serotonin at concentrations present in mast cells $(20 \mu \mathrm{g}$ and $2 \mu \mathrm{g}$ per million cells respectively) may induce immunomodulatory effects. For instance, histamine up-regulates macrophage synthesis of IL-1. ${ }^{29}$ However, histamine at concentrations in the range of $10^{-6}-10^{-3} \mathrm{M}$ (equalling and exceeding that present in MCG used in this study) failed to affect TNFo and NO production by macrophages (data not shown). These results are in agreement with our earlier report of MCG inhibition of macrophage superoxide production, which showed that unlike MCG, histamine and serotonin were ineffective in modulating the respiratory burst. ${ }^{9}$ The effect of serotonin on macrophage $\mathrm{NO}$ and $\mathrm{TNF} \alpha$ was not tested in this study. It is also noteworthy that histamine and serotonin are short-lived and their effects are rapidly lost after mast cell degranulation. Heparin is an important constituent of MCG and murine macrophages possess heparin receptors. ${ }^{30} \mathrm{~A}$ previous report has shown that commercial heparin and MCG are capable of inhibiting Fc $\gamma 2$ a receptor mediated phagocytosis in macrophage cell line. ${ }^{31}$ Although commercial heparin differs from rat MCGheparin, it is possible that MCG-heparin may have some modulatory effects on macrophage iNOS and TNF $\alpha$ expression. Our results presented here show that both MCG and MCG-sonicate are capable of degrading TNFo with loss of immunoreactivity and biological activity, and that both secreted and recombinant TNFo are susceptible. This indicates that the decreased levels of TNF $\alpha$ could be partially due to the proteolytic effects of MCG-proteases, in addition to the effect of MCG inhibition of macrophage TNFo mRNA expression. However, this proteolytic effect was only partially reversed by treatment of MCG with a mixture of protease inhibitors. The failure of protease inhibitors to completely abrogate the MCG effect may be due to incomplete inhibition of the protease activity or due to the absence of specific inhibitors for certain proteases.

Mast cell degranulation generates the release of a variety of inflammatory molecules that directly stimulate many cell types including epithelial cells, ${ }^{32}$ fibroblasts ${ }^{33}$ and endothelial cells. ${ }^{17}$ This study is the first evidence that mast cell granules inhibit macrophage TNF $\alpha$ and iNOS mRNA expression. We also found that the mast cell proteases degrade recombinant and macrophage secreted TNFa. The pre-and post-transcriptional regulation of TNF $\alpha$ production in LPS-activated macrophages by MCG may contribute to the inhibition of iNOS mRNA expression.

\section{References}

1. Adams DO, Hamilton TA. The cell biology of macrophage activation. Ann Rev Im munol 1984; 2: 283-318.
2. Adams DO, Hamilton TA. Molecular basis of macrophage activation. In: Lew is CE, McGee JO'D, eds. The Macrophages. New York: Oxford University Press, 1992; 75-114

3. Ishizaka T, Ishizaka K. Activation of mast cells for mediator release through IgE receptors. Prog Allergy 1984; 34: 188-235.

4. Schwartz LB, Austen KF. Structure and function of the chemical mediators of mast cells. Prog Allergy 1984; 34: 271-321.

5. Galli SJ, Lichtenstein LM. Biology of mast cells and basophils. In Middleton E Jr, ed. Allergy: principles and practices, 3rd edn. St Louis, MO: Mosby, 1988; 160 .

6. Holgate ST, Robinson C, Church MK. Mediators of immediate hypersensitivity. In: Middleton E Jr, ed. Allergy: principles and practices, 3rd edn. St Louis, MO: Mosby, 1988; 135

7. Fawcett DW. An experimental study of mast cell degranulation and regeneration. An at Rec 1955; 121: 29-43.

8. Dileepan KN, Stechschulte DJ. Influence of mast cells on macrophage function. Biochem Soc Trans 1986; 14: 913-914.

9. Dileepan KN, Simpson KM, Stechschulte DJ. Modulation of macrophage superoxide-induced cytochrome c reduction by mast cells. J Lab Clin Med 1989; 113: 577-585.

10. Shah BA, Li Y, Stechschulte DJ, Dileepan KN. Phagocytosis of mast cell granules results in decreased macrophage superoxide production. Med Inflam $m$ 1995; 4: 406-412.

11. Dileepan KN, Lorsbach R, Stechschulte DJ. Mast cell granules inhibit macrophage-mediated lysis of mastocytoma cells (P815) and nitric oxide production. J Leukoc Biol 1993; 53: 446-453.

12. Cawley EP, Hoch-Ligeti C. Association of tissue mast cells and skin tumors. Arch Dermatol 1961; 83:146-150.

13. Bowers HM, Mahapatro RC, Kennedy JW. Numbers of mast cells in the axillary lymph nodes of breast cancer patients. Cancer 1979; 43: $568-573$.

14. Roche WR. Mast cells and tumors. The specific enhancement of tumor proliferation in vitro. Am J Pathol 1985; 119: 57-64.

15. Qu Z, Liebler JM, Powers MR, Galey T, Ahmadi P, Huang XN, Ansel JC, Butterfield JH, Planck SR, Rosenbaum JT. Mast cells are a major source of basic fibroblast growth factor in chronic inflammation and cutaneous hemangioma. Am J Pathol 1995; 147: 564-573.

16. Kaartinen M, Penttila A, Kovanen PT. Mast cells accompany microvessels in human coronary atheromas: implications for intimal neovascularization and hemorrhage. Atherosclerosis. 1996; 123: $123-131$.

17. Li Y, Stechschulte AC, Smith DD, Lindsley HB, Stechschulte DJ, Dileepan $\mathrm{KN}$. Mast cell granules potentiate endotoxin-induced interleukin-6 production by endothelial cells. J Leukoc Biol 1997; 62: 210-216.

18. Raphael GD, Henderson WR, Kaliner M. Isolation of me mbrane-bound rat mast cell granules. Exp Cell Res 1978; 115: 428-431.

19. Li Y, Ito N, Suzuki T, Stechschulte DJ, Dileepan KN. Dexamethasone inhibits nitric oxide-mediated cytotoxicity via effect on both macrophages and target cells. Im munopharmacology 1995; 30: 177-186.

20. Yurt R, Austen KF. Preparative purification of the rat mast cell chymase: characterization and interaction with granule components. J Exp Med 1977; 146: 1405-1419.

21. Woodbury RG, Everitt MT, Neurath H. Mast cell proteases. Meth Enzymol 1981; 80: 588-609.

22. Kokkonen JO, Vartiainen M, Kovanen PT. Low density lipoprotein degradation by secretory granules of rat mast cells. Sequential degradation of apolipoprotein B by granule chymase and carboxypeptidase A. $J$ Biol Chem 1986; 261: 16067-16072.

23. Schwartz LB, Irani AM, Roller K, Castells MC, Schechter NM. Quantitation of histamine, tryptase and chymase in dispersed human T and TC mast cells. I Im munol 1987; 138: 2611-2615.

24. Thiemermann C, Wu CC, Szabo C, Perretti M, Vane JR. Role of tumour necrosis factor in the induction of nitric oxide synthase in a rat model of endotox in shock. Br J Pharm acol 1993; 110: 177-182.

25. Geller DA, de Vera ME, Russell DA, Shapiro RA, Nussler AK, Simmons RL, Billiar TR. A central role for IL-1 $\beta$ in the in vitro and in vivo regulation of hepatic inducible nitric oxide synthase. J Immunol 1995; 155: 4890-4898

26. Salkowski CA, Detore G, McNally R, van-Rooijen N, Vogel SN. Regulation of inducible nitric oxide synthase messenger RNA expression and nitric oxide production by lipopolysaccharide in vivo: the roles of macrophages, endogenous IFN $\gamma$, and TNF receptor-1-mediated signaling. $J$ Im munol 1997; 158: 905-912.

27. Marchant A, Gueydan C, Houzet L, Amraoui Z, Sels A, Huez G, Goldman M, Kruys V. Defective translation of tumor necrosis factor mRNA in lipopolysaccharide-tole rant macrophages. J Inflamm 1996; 46: $114-123$.

28. Lorsbach RB, Murphy WJ, Lowenstein CJ, Snyder SH, Russell SW. Expression of the nitric oxide synthase gene in mouse macrophages activated for tumor cell killing. J Biol Chem 1993; 268: 1908-1913.

29. Okamoto H, Nakano K. Regulation of interleukin-1 synthesis by histamine produced by mouse peritoneal macrophages per se. Im $m u$ nology 1990; 69: 162-165.

30. Bleiberg I, MacGregor I, Aronson M. Heparin receptors on mouse macrophages. Throm $b$ Res 1983; 29: 53-61.

31. Yamada A, Dileepan KN, Stechschulte DJ, Suzuki T. Regulation of Fc $\gamma 2$ a receptor-mediated phagocytosis by a murine macrophage like cell line, 
P388D1. Involvement of casein kinase II activity associated with Fc r2a receptor. J Mol Cell Im munol 1989; 4: 191-202.

32. Cairns JA, Walls AF Mast cell tryptase is a mitogen for epithelial cells. Stimulation of IL-8 production and intercellular adhesion molecule-1 expression. J Im munol 1996; 156: 275-283.

33. Gruber BL, Kew RR, Jelaska A, Marchese MJ, Garlick J, Ren S, Schwartz LB, Korn JH. Human mast cells activate fibroblasts. Tryptase is a fibrogenic factor stimulating collagen messenger ribonucleic acid synthesis and fibroblast chemotax is. J Im m unol 1997; 158: 2310-2317.
ACKNOWLEDGEMENTS. This study was supported by grants from the American Heart Association (Kansas affiliate) and the University of Kansas Medical Center Research Institute, and by the Joseph and Elizabeth Carey Arthritis Funds, Hinman Fund, and Jones Fund from the KU Endow ment Association.

\section{Received 16 August 1998}

accepted 1 September 1998 


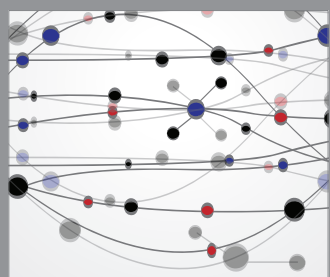

The Scientific World Journal
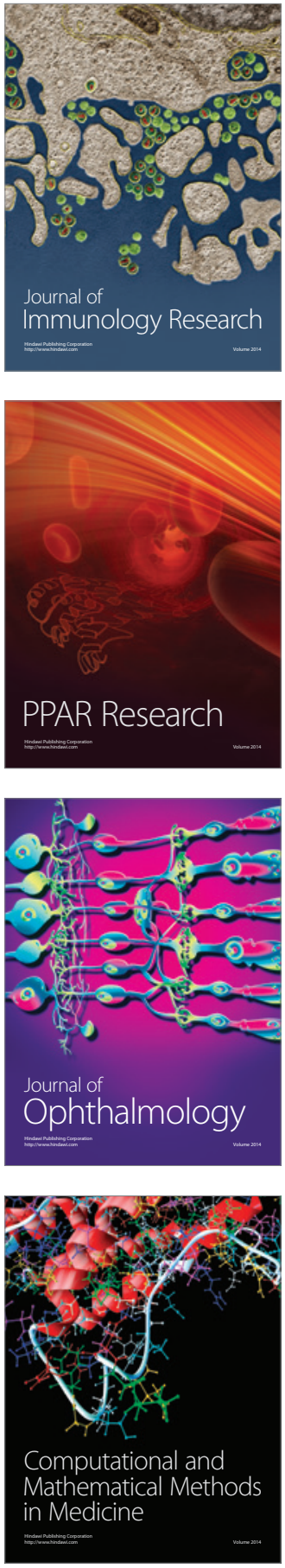

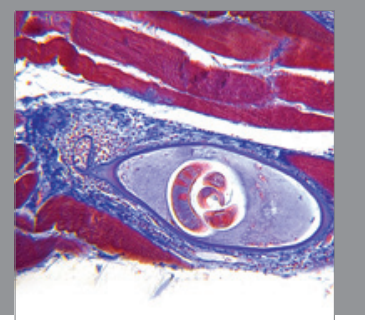

Gastroenterology

Research and Practice
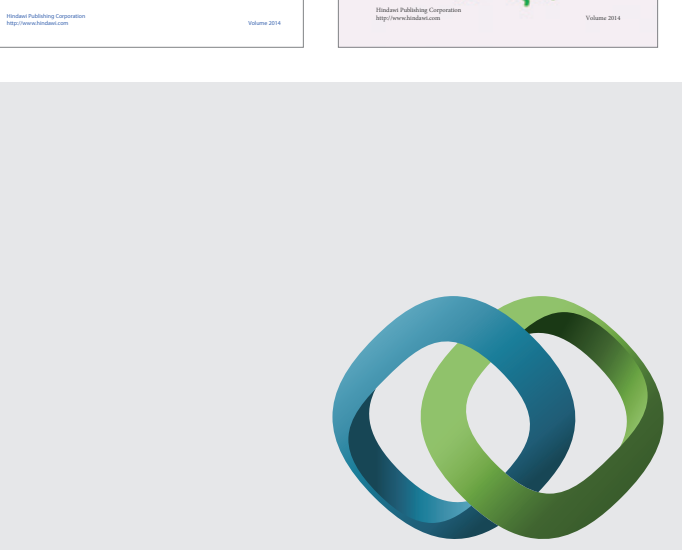

\section{Hindawi}

Submit your manuscripts at

http://www.hindawi.com
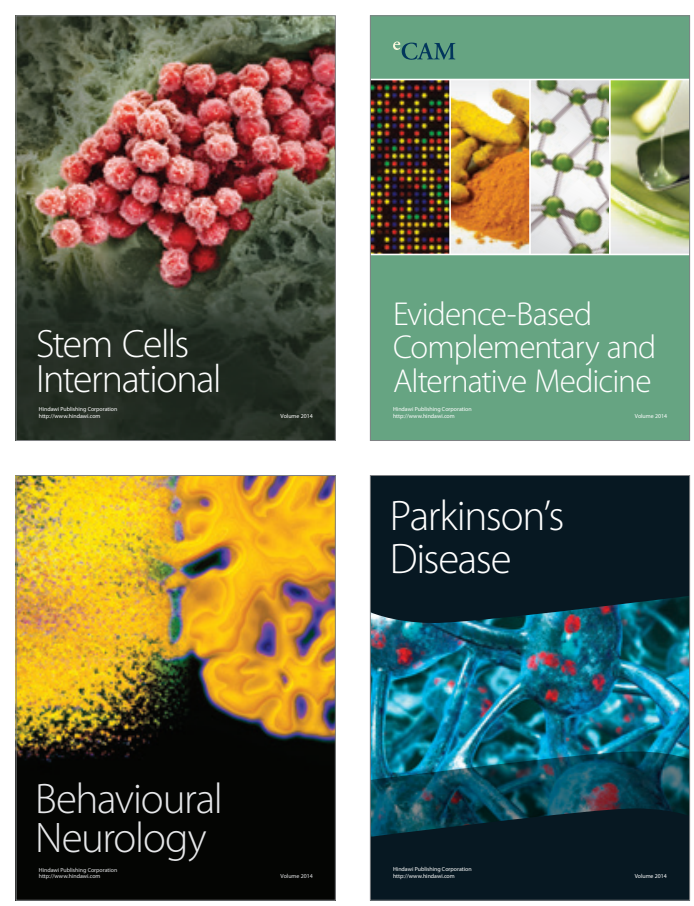

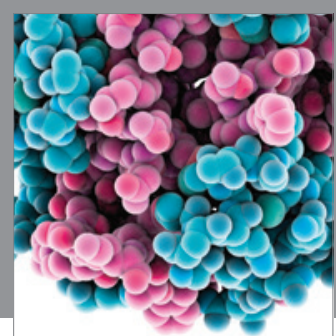

Journal of
Diabetes Research

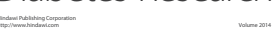

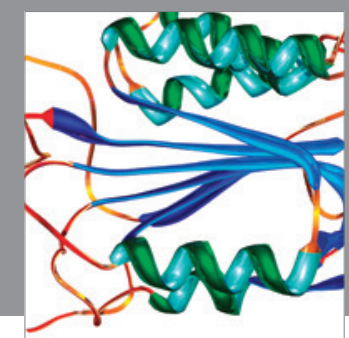

Disease Markers
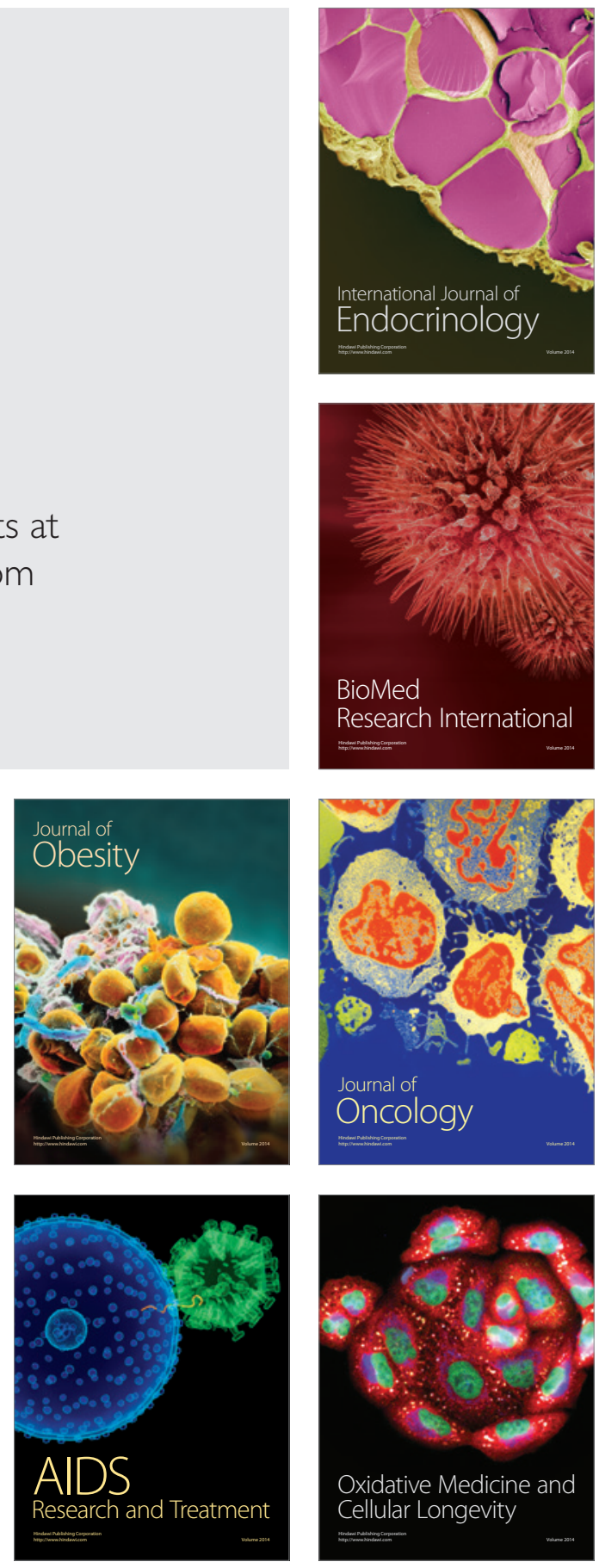